\title{
Relationship of Slaughter Age and Carcass Traits of Hanwoo Cattle
}

\author{
Panjono, Sun Moon Kang, Ik Sun Lee, Yeong-Jong Kim¹, and Sung Ki Lee* \\ Department of Animal Products and Food Science, Kangwon National University, Chuncheon 200-701, Korea \\ ${ }^{1}$ Pyoengchang, Yeongwol, Jeongseon Livestock of Cooperation, Pyeongchang 232-807, Korea
}

\begin{abstract}
Two experiments were carried out to investigate the relationship of slaughter age and carcass traits of Hanwoo cattle. A total number of 11,284 heads of cattle (4,624 bulls, 6,120 steers, and 540 females) were used in the experiment (Exp.) 1. In the Exp. 2, 3,887 heads of steers slaughtered at age of 24-36 mon were used. After $24 \mathrm{~h}$ post-slaughter chilling, the carcasses were weighed and evaluated by an official grader of carcass traits according to the Korean carcass grading standard. Backfat thickness was the main variable in yield index and grade whereas marbling score was the main variable in carcass quality grade. Meat color was an important factor affecting carcass quality grade of bulls; fat color was an important factor affecting those of steers and females; and maturity was an important factor affecting that of females. After 24-mon-old, extension of slaughter age did not automatically increase the quantity and quality of meat. However, 29 mon of age can be regarded as the optimum time to slaughter steers to attain the highest take home money for farmers.
\end{abstract}

Key words : slaughter age, carcass traits, Hanwoo cattle

\section{Introduction}

Hanwoo beef has been regarded as the most expensive and high quality beef in South Korea (Kim and Lee, 2003). It is a hybrid of Bos Taurus $\times$ Bos zebu which was settled in the Korean Peninsula in BC 4000 (Rhee and Kim, 2001). To evaluate and appraise the quality of beef, the Korean government introduced beef carcass grading system in 1992. The carcass grading system consists of yield and quality grades, and the final carcass grade is assessed by combination of them. The yield grade is based on the backfat thickness, ribeye area, and carcass weight. In addition to meat color, fat color, firmness, and maturity, the carcass quality grade is based on the marbling status (Kim and Lee, 2003; NLCF, 2004).

It is important to know the relationship between slaughter age and carcass traits to develop the strategy for improving the quantity and quality of meat. Park et al. (2002) have studied the influence of slaughter weight and sex on yield and quality of Hanwoo carcass. In advance, Lee et al. (2005) have studied the relationship between yield traits and cutability to develop the yield prediction

*Corresponding author : Sung Ki Lee, Dept. of Animal Products and Food Science, Kangwon National University, Chuncheon 200-701, Korea. Tel: +82-33-250-8646; Fax: +82-33-251-7719; E-mail: skilee@kangwon.ac.kr equation of Hanwoo carcass. For other purposes, Moon et al. (2003) have studied carcass traits determining yield and quality grades of Hanwoo steers. However, relationship among carcass traits of Hanwoo bulls and females haven't been studied yet. Therefore, the experiment (Exp.) 1 was carried out to investigate the relationship of carcass traits of Hanwoo bulls, steers, and females. In addition, Moon et al. (2003) studied animal slaughtered at around 24 mon of age whereas, in general, farmers slaughter their cattle at around 30-mon-old. Therefore, to make better understood, the Exp. 2 investigated the relationship of slaughter age and carcass traits of Hanwoo steers at 2436-mon-old.

\section{Materials and Methods}

There were two experiments conducted to investigate the relationship of slaughter age and carcass traits in Hanwoo cattle. A total number of 11,284 heads of cattle (4,624 bulls, 6,120 steers, and 540 females) from Gangwon Province, Republic of Korea, were used in the Exp. 1. The data were collected from the cattle which were slaughtered at the municipal slaughterhouse. They were slaughtered following normal commercial slaughterhouse procedure. After $24 \mathrm{~h}$ post-slaughter chilling, the carcasses were weighed and evaluated by an official grader of carcass traits according to the Korean carcass grading 


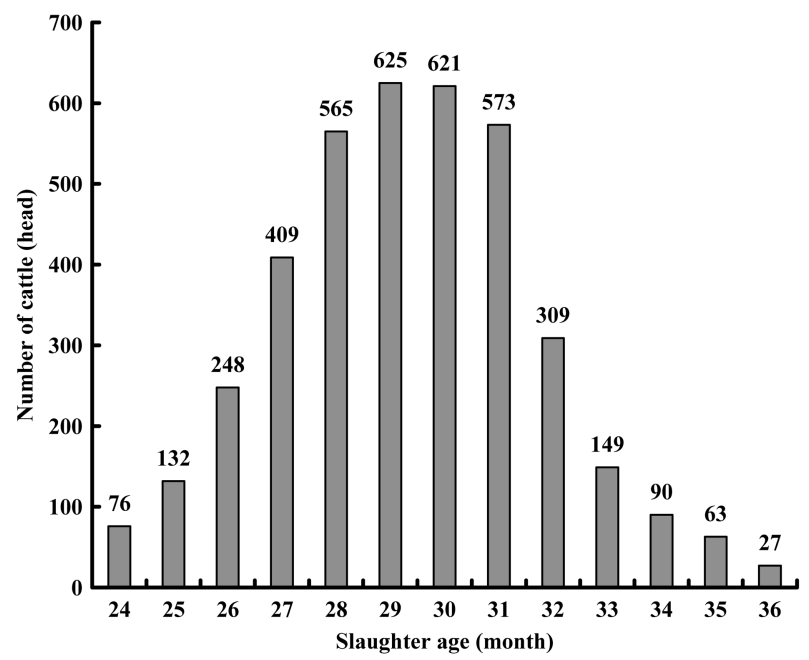

Fig. 1. Distribution of Hanwoo steers based on the slaughter age.

standard (NLCF, 2004). The detail of carcass grade was described by Lee et al. (2008). The correlation among carcass traits was investigated by two-tailed Pearson's bivariate correlation analysis. Curve estimation analysis was used to obtain the estimation equation between firmness and marbling scores. The equation of carcass quality grade was attained by backward linear regression analysis.

In the Exp. 2, 3,887 heads of steers were used. The origin of animals was the same as the origin of animal at Exp. 1. The samples were selected from animal which were slaughtered at 24-36 mon of age. The number distribution of steers based on the slaughter age is presented at Fig. 1. The grading methods were the same as grading methods at Exp. 1. The correlation between slaughter age and carcass traits was investigated by two-tailed Pear- son's bivariate correlation analysis. The carcass prices (Won/kg) from January 2005 to June 2008 were cited from APGS (2008). All of statistical analyses in Exp. 1 and 2 were performed using the SPSS 12 for windows (SPSS, 2003).

\section{Results and Discussion}

Results of the Exp. 1 were presented in Tables 1, 2 and Fig. 2 and results of the Exp. 2 were presented in Tables 3, 4 and Fig. 3.

The carcass yield grade of bulls was higher $(p<0.05)$ than that of steers and females. Inversely, the carcass quality grade of bulls was lower $(p<0.05)$ than that of steers and females (Table 1). It is well recognized that muscle growth is greater in males than females, and castration results in diminished muscle growth (Lindsay, 1983). Entire males grow faster, have a larger mature size and have leaner carcasses at normal slaughter weight than castrates, which in turn grow faster and are leaner than females. Castration results in increased fat and slightly decreased muscle deposition in the carcass (Kirton and Morris, 1989). All of carcass traits values were significantly different between bulls, steers, and females so that the relationship among carcass traits was analyzed separately.

Correlation coefficients of carcass traits are presented in Table 2. Those were similar between bulls, steers, and females. In accordance with yield index equation, the main variable affecting yield index and grade was backfat thickness whereas carcass weight and ribeye area were less influenced. Backfat thickness is a significant determinant of Hanwoo yield, as shown for other breeds, and the

Table 1. Comparison of the carcass traits of Hanwoo bulls, steers and, females

\begin{tabular}{crrr}
\hline \hline Traits & \multicolumn{1}{c}{ Bull } & \multicolumn{1}{c}{ Steer } & Female \\
\hline Yield traits & & & $327.84 \pm 47.04^{\mathrm{c}}$ \\
Carcass weight $(\mathrm{kg})$ & $376.33 \pm 44.67^{\mathrm{b}}$ & $397.87 \pm 44.30^{\mathrm{a}}$ & $12.54 \pm 5.99^{\mathrm{a}}$ \\
Backfat thickness (mm) & $6.61 \pm 3.22^{\mathrm{c}}$ & $11.98 \pm 5.26^{\mathrm{b}}$ & $79.45 \pm 11.51^{\mathrm{b}}$ \\
Ribeye area $\left(\mathrm{cm}^{2}\right)$ & $86.25 \pm 9.71^{\mathrm{a}}$ & $86.63 \pm 9.78^{\mathrm{a}}$ & $66.03 \pm 4.06^{\mathrm{c}}$ \\
Yield index & $69.46 \pm 2.48^{\mathrm{a}}$ & $65.63 \pm 3.85^{\mathrm{b}}$ & $2.21 \pm 0.67^{\mathrm{b}}$ \\
Yield grade & $2.80 \pm 0.42^{\mathrm{a}}$ & $2.20 \pm 0.67^{\mathrm{b}}$ & $3.94 \pm 2.03^{\mathrm{b}}$ \\
Quality traits & & & $5.10 \pm 0.57^{\mathrm{a}}$ \\
Marbling score & $1.60 \pm 1.05^{\mathrm{c}}$ & $5.42 \pm 2.00^{\mathrm{a}}$ & $3.33 \pm 0.70^{\mathrm{a}}$ \\
Meat color score & $4.98 \pm 0.48^{\mathrm{c}}$ & $4.82 \pm 0.47^{\mathrm{b}}$ & $1.72 \pm 0.49^{\mathrm{b}}$ \\
Fat color score & $2.99 \pm 0.17^{\mathrm{c}}$ & $3.02 \pm 0.27^{\mathrm{b}}$ & $6.12 \pm 2.02^{\mathrm{a}}$ \\
Firmness score & $1.95 \pm 0.26^{\mathrm{a}}$ & $1.24 \pm 0.43^{\mathrm{c}}$ & $2.11 \pm 0.32^{\mathrm{b}}$ \\
Maturity score & $2.07 \pm 0.29^{\mathrm{c}}$ & $3.45 \pm 1.01^{\mathrm{a}}$ & $2.41 \pm 1.05^{\mathrm{b}}$ \\
Carcass quality grade & $1.42 \pm 0.65^{\mathrm{c}}$ & & \\
\hline
\end{tabular}

${ }^{\mathrm{a}-\mathrm{c}}$ Means \pm S.D. in the same row with different superscripts are significantly different $(p<0.05)$. 
Table 2. Correlation coefficients of carcass traits of Hanwoo cattle

\begin{tabular}{|c|c|c|c|c|c|c|c|c|c|c|c|}
\hline Variables & Sex & $\begin{array}{l}\text { Backfat } \\
\text { thickness } \\
(\mathrm{mm})\end{array}$ & $\begin{array}{l}\text { Ribeye } \\
\text { area } \\
\left(\mathrm{cm}^{2}\right)\end{array}$ & $\begin{array}{l}\text { Yield } \\
\text { index }\end{array}$ & $\begin{array}{l}\text { Yield } \\
\text { grade }\end{array}$ & $\begin{array}{l}\text { Marbling } \\
\text { score }\end{array}$ & $\begin{array}{l}\text { Meat color } \\
\text { score }\end{array}$ & $\begin{array}{l}\text { Fat color } \\
\text { score }\end{array}$ & $\begin{array}{l}\text { Firmness } \\
\text { score }\end{array}$ & $\begin{array}{l}\text { Maturity } \\
\text { score }\end{array}$ & $\begin{array}{c}\text { Carcass } \\
\text { quality } \\
\text { grade }\end{array}$ \\
\hline \multirow{3}{*}{$\begin{array}{l}\text { Carcass weight } \\
(\mathrm{kg})\end{array}$} & Bull & $0.213 * *$ & $0.635 * *$ & $-0.281 * *$ & $-0.202 * *$ & $0.057 * *$ & $0.030 *$ & $0.043 * *$ & $-0.029 *$ & $0.360 * *$ & $0.063 * *$ \\
\hline & Steer & $0.348 * *$ & $0.524 * *$ & $-0.400 * *$ & $-0.337 * *$ & $0.126^{* *}$ & $-0.068 * *$ & $0.029 *$ & $-0.239 * *$ & $0.199 * *$ & $0.311^{* *}$ \\
\hline & Female & $0.460 * *$ & $0.681 * *$ & $-0.452 * *$ & $-0.364 * *$ & $0.234 * *$ & $0.024^{\mathrm{NS}}$ & $-0.007^{\mathrm{NS}}$ & $-0.128 * *$ & $0.087 *$ & $0.198 * *$ \\
\hline \multirow{3}{*}{$\begin{array}{l}\text { Backfat thickness } \\
(\mathrm{mm})\end{array}$} & Bull & & $-0.025^{\mathrm{NS}}$ & $-0.917 * *$ & $-0.778 * *$ & $0.240 * *$ & $-0.169 * *$ & $0.033^{*}$ & $-0.130 * *$ & $0.042 * *$ & $0.262 * *$ \\
\hline & Steer & & $-0.036^{* *}$ & $-0.960 * *$ & $-0.842 * *$ & $-0.010^{\mathrm{NS}}$ & $-0.107 * *$ & $0.024^{\mathrm{NS}}$ & $-0.018^{\mathrm{NS}}$ & $0.119 * *$ & $-0.003^{\mathrm{NS}}$ \\
\hline & Female & & $0.238 * *$ & $-0.963 * *$ & $-0.815 * *$ & $0.131^{* *}$ & $0.022^{\mathrm{NS}}$ & $0.044^{\mathrm{NS}}$ & $0.045^{\mathrm{NS}}$ & $0.138^{* *}$ & $0.071^{\mathrm{NS}}$ \\
\hline \multirow{3}{*}{$\begin{array}{l}\text { Ribeye area } \\
\left(\mathrm{cm}^{2}\right)\end{array}$} & Bull & & & $0.255^{* *}$ & $0.138 * *$ & $-0.018^{\mathrm{NS}}$ & $0.024^{\mathrm{NS}}$ & $0.022^{\mathrm{NS}}$ & $-0.001^{\mathrm{NS}}$ & $0.221 * *$ & $-0.017^{\mathrm{NS}}$ \\
\hline & Steer & & & $0.217 * *$ & $0.190 * *$ & $0.321^{* *}$ & $-0.068 * *$ & $0.029 *$ & $-0.239 * *$ & $0.199 * *$ & $0.311^{* *}$ \\
\hline & Female & & & $-0.040^{\mathrm{NS}}$ & $-0.014^{\mathrm{NS}}$ & $0.170 * *$ & $0.067^{\mathrm{NS}}$ & $-0.044^{\mathrm{NS}}$ & $-0.093^{*}$ & $0.036^{\mathrm{NS}}$ & $0.161 * *$ \\
\hline \multirow[t]{3}{*}{ Yield index } & Bull & & & & $0.788 * *$ & $-0.229 * *$ & $0.138^{* *}$ & $-0.034 *$ & $0.118^{* *}$ & $-0.078^{* *}$ & $-0.249 * *$ \\
\hline & Steer & & & & $0.874 * *$ & $0.081 * *$ & $0.079 * *$ & $-0.013^{\mathrm{NS}}$ & $-0.026^{*}$ & $-0.136 * *$ & $0.069 * *$ \\
\hline & Female & & & & $0.848 * *$ & $-0.124 * *$ & $0.003^{\mathrm{NS}}$ & $-0.055^{\mathrm{NS}}$ & $-0.040^{\mathrm{NS}}$ & $-0.139^{\mathrm{NS}}$ & $-0.061^{\mathrm{NS}}$ \\
\hline \multirow[t]{3}{*}{ Yield grade } & Bull & & & & & $-0.177 * *$ & $0.110^{* *}$ & $-0.035^{*}$ & $0.077 * *$ & $-0.057 * *$ & $-0.188 * *$ \\
\hline & Steer & & & & & $0.054 * *$ & $0.088^{* *}$ & $-0.022^{\mathrm{NS}}$ & $-0.003^{\mathrm{NS}}$ & $-0.112 * *$ & $0.043 * *$ \\
\hline & Female & & & & & $-0.092 *$ & $-0.045^{\mathrm{NS}}$ & $-0.044^{\mathrm{NS}}$ & $-0.020^{\mathrm{NS}}$ & $-0.139 * *$ & $0.033^{\mathrm{NS}}$ \\
\hline \multirow[t]{3}{*}{ Marbling score } & Bull & & & & & & $-0.238 * *$ & $0.006^{\mathrm{NS}}$ & $-0.692 * *$ & $-0.007^{\mathrm{NS}}$ & $0.952 * *$ \\
\hline & Steer & & & & & & $-0.132 * *$ & $0.038 * *$ & $-0.701 * *$ & $0.035 * *$ & $0.967 * *$ \\
\hline & Female & & & & & & $-0.130 * *$ & $0.012^{\mathrm{NS}}$ & $-0.551 * *$ & $-0.009^{\mathrm{NS}}$ & $0.863 * *$ \\
\hline \multirow[t]{3}{*}{ Meat color score } & Bull & & & & & & & $0.020^{\mathrm{NS}}$ & $0.248 * *$ & $0.080^{* *}$ & $-0.252 * *$ \\
\hline & Steer & & & & & & & $0.089 * *$ & $0.199 * *$ & $0.021^{\mathrm{NS}}$ & $-0.132 * *$ \\
\hline & Female & & & & & & & $0.328 * *$ & $0.320 * *$ & $0.307 * *$ & $-0.248 * *$ \\
\hline \multirow[t]{3}{*}{ Fat color core } & Bull & & & & & & & & $-0.002^{\mathrm{NS}}$ & $0.056 * *$ & $0.003^{\mathrm{NS}}$ \\
\hline & Steer & & & & & & & & $-0.012^{\mathrm{NS}}$ & $-0.015^{\mathrm{NS}}$ & $0.027 *$ \\
\hline & Female & & & & & & & & $0.210 * *$ & $0.347 * *$ & $-0.175^{* *}$ \\
\hline \multirow[t]{3}{*}{ Firmness score } & Bull & & & & & & & & & $0.012^{\mathrm{NS}}$ & $-0.635^{* *}$ \\
\hline & Steer & & & & & & & & & $0.009^{\mathrm{NS}}$ & $-0.704 * *$ \\
\hline & Female & & & & & & & & & $0.323^{* *}$ & $-0.705^{* *}$ \\
\hline \multirow[t]{3}{*}{ Maturity score } & Bull & & & & & & & & & & $-0.016^{\mathrm{NS}}$ \\
\hline & Steer & & & & & & & & & & $0.036^{* *}$ \\
\hline & Female & & & & & & & & & & $-0.284 * *$ \\
\hline
\end{tabular}

NS, non significant; $* p<0.05, * * p<0.01$.

inclusions of backfat thickness in the prediction equation considerably improved fatness compared with that estimated from hot carcass weight and ribeye area (Lee et al., 2005). Some researchers have criticized the use of carcass weight as an independent variable for predicting cutability, claiming that equations in which it is included discriminate against fast-growing cattle with heavy mature weights (Abraham et al., 1980). Ribeye area is recognized as an important factor in predicting yield grade but there are disadvantages associated with double muscling (Turner et al., 1990). Ribeye area may be more useful in populations of similar weight than in those varying widely in weight (Crouse et al., 1975).

Yield index and grade had negative correlation with backfat thickness (Table 2); the higher backfat thickness, the lower yield index and grade. Kirton (1989) stated that fat cover has always been considered as a factor of major importance in carcass classification because yield of muscle and/or saleable meat (where fat-trimmed meat is sold) decreases as carcass fat content increases.

Correlation analysis of yield traits showed that carcass weight and ribeye area have the highest relationship compared to backfat thickness, and carcass weight or ribeye area. Lawrence et al. (2008) stated that the reason why the perception that carcass weight and ribeye area are linked in a significant manner is likely due to the assumed relationship predicted by equation, and the actual relationship is weak.

Carcass quality grade was mainly determined by the marbling score; the higher marbling score, the higher car- 


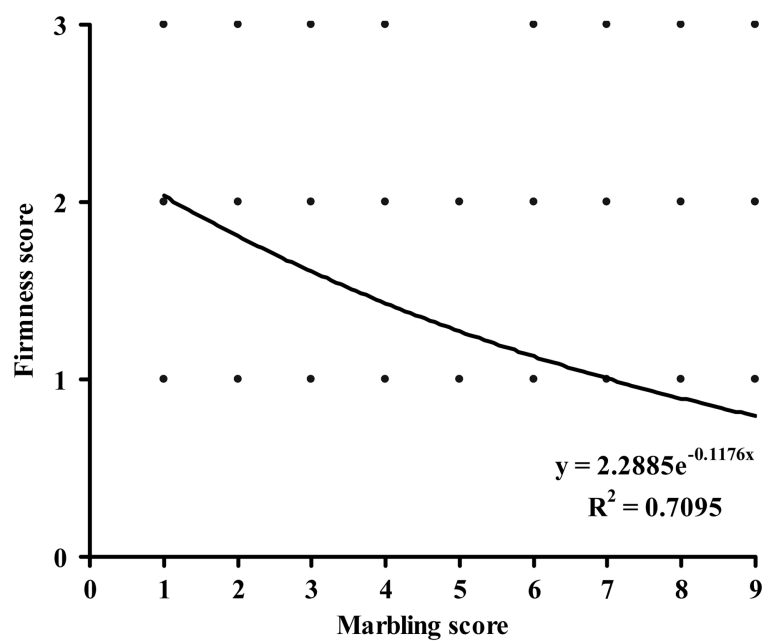

Fig. 2. Relationship of marbling and firmness scores of Hanwoo carcasses.

cass quality grade. Scollan et al. (2006) stated that marbling fat refers to the white flecks or streaks of adipose tissue between the bundles of muscle fibers, so that it is closely linked to intramuscular fat (IMF) content. Miller (1994) described that beef carcasses containing a higher level of IMF are eligible for a higher-quality grade and a carcass with a higher-quality grade would be expected to produce meat with more desirable palatability than that with a lower-quality grade. Tatum et al. (1982) reported that marbling had a low but positive relationship with all of the palatability traits of beef, i.e. flavor desirability, juiciness, amount of detectable connective tissue, overall tenderness, and overall palatability.

Even though carcass quality grade was mainly determined by the marbling score, firmness also has relatively high relationship with carcass quality grade. This might due to the high relationship of marbling and firmness scores. Firmness score had negative correlation with marbling score (Table 2), the higher marbling score, the lower firmness score (Fig. 2). This result was in accordance with the previous studies which found that carcasses with higher degrees of marbling were significantly firmer than those with lower degrees of marbling (Breidenstein et al., 1968; McBee and Wiles, 1967). The firmness is defined as the ability of a piece of meat to retain its shape when on display and it is influenced by fat content because carcass chilling makes fat much firmer than muscle (Judge et al., 1989; Purchas, 1989).

Regression analysis which included all of carcass quality traits to quality grade revealed that marbling and firmness scores were included in the equation for all sex condition; meat color score was included in the equation for bulls; and fat color and maturity scores were included
Table 3. Correlation coefficients of slaughter age and carcass traits of Hanwoo steers

\begin{tabular}{lc}
\hline \hline Dependent variables & Correlation coefficients \\
\hline Carcass weight $(\mathrm{kg})$ & $0.244^{* *}$ \\
Dressing percentage $(\%)$ & $-0.048^{* *}$ \\
Backfat thickness $(\mathrm{mm})$ & $0.095^{* *}$ \\
Ribeye area $\left(\mathrm{cm}^{2}\right)$ & $0.045^{* *}$ \\
Yield index & $-0.127^{* *}$ \\
Yield grade & $-0.112^{* *}$ \\
Marbling & $-0.112^{* *}$ \\
Meat color & $0.139^{* *}$ \\
Fat color & $-0.030^{\mathrm{NS}}$ \\
Firmness & $0.103^{* *}$ \\
Maturity & $0.172^{* *}$ \\
Carcass quality grade & $-0.108^{* *}$ \\
\hline
\end{tabular}

NS, non significant; $* * p<0.01$.

in the equation for females. The regression equations for carcass quality grades of bulls, steers, and females were presented in Equation (Eq.) 1, 2, and 3, respectively. The coefficients of determination $\left(\mathrm{R}^{2}\right)$ of Eq. (1), (2), and (3) were $0.909,0.936$, and 0.860 , respectively.

Carcass quality grade $=0.405+(0.606 \times$ marbling score $)-$ $(0.042 \times$ meat color score $)+(0.131 \times$ firmness score $)$

Carcass quality grade $=1.150+(0.470 \times$ marbling score $)-$ ( $0.033 \times$ fat color score $)-(0.118 \times$ firmness score $)$

Carcass quality grade $=2.671+(0.384 \times$ marbling score $)-$ (0.112×fat color score $)-(0.482 \times$ firmness score $)-(0.094 \times$ maturity score)

Eq. (1) indicated that meat color score was an important factor affecting bulls' carcass quality grade. This can be explained by their temperament. Bulls are more temperamental than other sex conditions so that they are more easily to be stressed which contribute to darker meat (Field, 1971).

Fat color score was an important factor affecting carcass quality grade of steers and females (Eq. (2)). This might be because of the maturity stage of them. The maturity score of females was significantly higher $(p<0.01)$ than that of steers which in turn significantly higher $(p<0.01)$ than that of bulls (Table 1). There is likelihood of fat being yellow is greater for older animals, and the fat color of most concern for beef is excessive yellowness, as most consumers associate a white to creamy color with good quality (Purchas, 1989).

Eq. (3) indicated that maturity score was an important factors affecting females' carcass quality grade. This 
Table 4. Proportion of carcass grade and price with slaughter age and carcass grade of Hanwoo steers

\begin{tabular}{|c|c|c|c|c|c|c|c|c|c|c|c|c|c|c|}
\hline \multirow{3}{*}{ Carcass grade } & \multicolumn{13}{|c|}{ Slaughter age (mon) } & \multirow{3}{*}{$\begin{array}{c}\text { Carcass } \\
\text { price }^{1)} \\
-(W o n / k g)\end{array}$} \\
\hline & 24 & 25 & 26 & 27 & 28 & 29 & 30 & 31 & 32 & 33 & 34 & 35 & 36 & \\
\hline & \multicolumn{13}{|c|}{ Percentage $(\%)$} & \\
\hline $1^{++} \mathrm{A}$ & 6.58 & 6.82 & 6.85 & 9.78 & 8.50 & 8.00 & 5.48 & 5.41 & 4.85 & 4.70 & 4.44 & 6.35 & 3.70 & 18,387 \\
\hline $1^{++} \mathrm{B}$ & 7.89 & 4.55 & 8.47 & 8.80 & 6.73 & 10.08 & 7.41 & 4.19 & 3.56 & 6.71 & 5.56 & 9.52 & 0.00 & 18,043 \\
\hline $1^{++} \mathrm{C}$ & 0.00 & 0.00 & 2.42 & 1.22 & 1.06 & 1.12 & 0.81 & 1.05 & 1.29 & 1.34 & 2.22 & 1.59 & 7.41 & 16,597 \\
\hline $1^{+} \mathrm{A}$ & 7.89 & 12.88 & 17.34 & 13.94 & 13.45 & 13.28 & 12.08 & 13.26 & 7.77 & 7.38 & 7.78 & 9.52 & 7.41 & 16,521 \\
\hline $1^{+} \mathrm{B}$ & 22.37 & 22.73 & 22.18 & 26.89 & 23.89 & 23.20 & 21.26 & 19.55 & 21.68 & 20.81 & 15.56 & 19.05 & 11.11 & 15,819 \\
\hline $1^{+} \mathrm{C}$ & 2.63 & 2.27 & 5.65 & 3.91 & 7.43 & 5.76 & 7.25 & 8.55 & 5.50 & 4.70 & 5.56 & 4.76 & 2.22 & 14.720 \\
\hline $1 \mathrm{~A}$ & 19.74 & & 12.10 & 10.02 & & 8.32 & & 6.98 & 8.74 & 4.03 & 11.11 & 9.52 & 3.70 & 15,270 \\
\hline $1 \mathrm{~B}$ & 14.47 & 15.15 & 11.69 & 14.18 & 13.45 & 14.72 & 15.46 & 16.58 & 19.09 & 18.12 & 15.56 & 15.87 & 14.81 & 13,833 \\
\hline $1 \mathrm{C}$ & & & 2.42 & & & 4.32 & & 7.68 & 11.65 & 7.38 & 4.44 & & 3.70 & 12,988 \\
\hline $2 \mathrm{~A}$ & 6.58 & 7.58 & 2.82 & 1.22 & 2.48 & 2.24 & 4.83 & 4.19 & 2.59 & 7.38 & 3.33 & 4.76 & 7.41 & 13,699 \\
\hline $2 \mathrm{~B}$ & 6.58 & 8.33 & 5.24 & 6.11 & 5.13 & 5.60 & 7.57 & 6.81 & 8.74 & 9.40 & 10.00 & 9.52 & 7.41 & 10,756 \\
\hline $2 \mathrm{C}$ & 1.32 & 3.03 & 2.42 & 0.98 & 3.36 & 2.40 & 4.03 & 4.89 & 3.56 & 4.03 & 8.89 & 4.76 & 11.11 & 10,435 \\
\hline $3 \mathrm{~A}$ & 0.00 & 0.00 & 0.00 & 0.00 & 0.53 & 0.32 & 0.48 & 0.35 & 0.00 & 2.01 & 1.11 & 0.00 & 0.00 & 11,096 \\
\hline $3 B$ & 0.00 & 0.00 & 0.00 & 0.00 & 0.18 & 0.32 & 0.48 & 0.17 & 0.00 & 2.01 & 1.11 & 0.00 & 0.00 & 7,900 \\
\hline $3 \mathrm{C}$ & 1.32 & 0.76 & 0.40 & 0.49 & 0.00 & 0.32 & 0.16 & 0.35 & 0.97 & 0.00 & 3.33 & 1.59 & 0.00 & 6,444 \\
\hline Total & 100.00 & 100.00 & 100.00 & 100.00 & 100.00 & 100.00 & 100.00 & 100.00 & 100.00 & 100.00 & 100.00 & 100.00 & 100.00 & \\
\hline \multirow{2}{*}{ 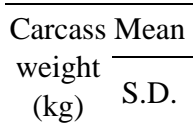 } & 374.43 & 383.27 & 389.37 & 393.00 & 400.76 & 404.38 & 406.75 & 418.23 & 417.59 & 414.77 & 41.9 .33 & 410.03 & 423.52 & \\
\hline & 40.68 & 35.39 & 37.15 & 33.99 & 35.77 & 36.32 & 39.53 & 42.76 & 44.21 & 50.41 & 48.81 & 65.03 & 48.23 & \\
\hline
\end{tabular}

might be due to the females were slaughtered at mature age. The maturity score of females was much higher than those of bulls and steers (Table 1). Judge et al. (1989) described that, in general, meat from physiologically mature animals is less tender than that from immature as reflects qualitative changes occurring in muscle connective tissue (collagen).

Fat deposition (intramuscular and subcutaneous fat) was the main factor affecting yield and carcass quality grades. However, there was only little correlation between backfat thickness and marbling score (Table 2). This might due to the different growth pattern between them. The development of marbling is late maturing, it is due to maintained or increased fat synthesis in combination with declining muscle growth as animal get older (Scollan et al., 2006). IMF grows at similar rates relative to total carcass fat while the growth of subcutaneous fat is faster (Davies, 1989). It seems to be an opportunity to accelerate marbling formation and slow backfat formation in the same time.

Table 3 shows that there was only small correlation between slaughter age and backfat thickness as well as marbling score. These indicated that, after 24-mon-old, slaughter age only had a small influence on the deposition of fat. Interestingly, marbling score had negative correlation with slaughter age whereas backfat thickness had positive correlation (Table 3). Table 3 also shows that dressing percentage, yield, and carcass quality grades had negative correlations with slaughter age. These indicated that extension of slaughter age did not automatically increase the quantity and quality of meat. This might be due to the optimum live weight for maximum yield and carcass quality grades that have been reached at 24-monold. Current study showed that the live weight of Hanwoo steers at 24 -mon-old was $624.34 \pm 63.03 \mathrm{~kg}$. Park et al. (2002) reported that yield grade was not improved with live weights greater than $551 \mathrm{~kg}$. Moon et al. (2003) reported that linear increase in marbling score was com-

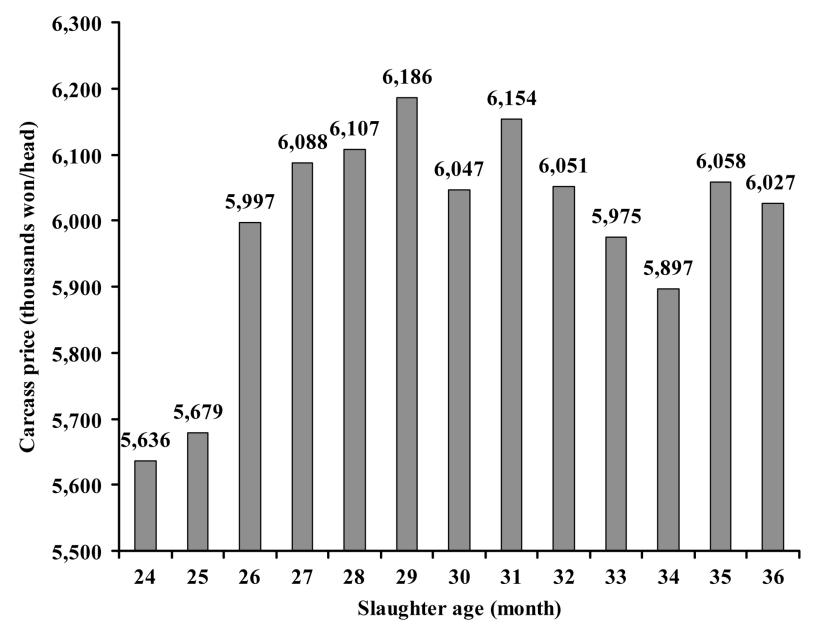

Fig. 3. Total carcass price of Hanwoo steers with different slaughter age. 
pleted by approximately $570 \mathrm{~kg}$ of slaughter weight. However, since the carcass price is decided by the combination of yield and carcass quality grades and the farmers' income is based on the carcass price and carcass weight, it is important to considerate the carcass weight. Carcass weight had positive correlation with slaughter age (Table 3); the older cattle, the higher carcass weight. Table 4 presents the proportion of the combination of yield and carcass quality grades with different slaughter age and the price of carcass with different carcass grade. Fig. 3 showed that the highest total carcass price was attained at 29 mon of age so that it can be said that the best time to get the highest take home money for farmers is at that slaughter age.

\section{Acknowledgement}

This study was carried out with the support of the Institute of Animal Resources, Kangwon National University, Republic of Korea.

\section{References}

1. Abraham, H. C., Murphey, C. E., Cross, H. R., Smith, G. C., and Franks, W. J. Jr. (1980) Factors affecting beef carcass cutability: An evaluation of the USDA yield grades for beef. J. Anim. Sci. 50, 841-851.

2. APGS (2008) The price of carcass from the auction at wholesale trading center (in Korean). Animal Products Grading Service. http://www.apgs.co.kr. Accessed on November 18.

3. Breidenstein, B. B., Cooper, C. C., Cassens, R. G., Evans, G., and Bray, R. W. (1968) Influence of marbling and maturity on the palatability of beef muscle. I: Chemical and organoleptic considerations. J. Anim. Sci. 27, 1532-1541.

4. Crouse, J. D., Dikeman, M. E., Koch, R. M., and Murphey, C. E. (1975) Evaluation of traits in the USDA yield grade equation for predicting beef carcass cutability in breed groups differing in growth and fattening characteristics. $J$. Anim. Sci. 41, 548-553.

5. Davies, A. S. (1989) Growth changes in the meat carcass. In: Meat production and processing. Purchas. R. W., ButlerHogg, B. W., and Davies, A. S. (eds), Occasional Publication No. 11, New Zealand Society of Animal Production Inc., NZ, pp. 61-72.

6. Field, R. A. (1971) Effect of castration on meat quality and quantity. J. Anim. Sci. 32, 849-858.

7. Judge, M. D., Aberle, E. D., Forrest, J. C., Hedrick, H. B., and Merkel, R. A. (1989) Principle of meat science. 2nd ed, Kendall/Hunt Publishing Company, Iowa, USA.

8. Kim, C. J. and Lee, E. S. (2003) Effects of quality grade on the chemical, physical and sensory characteristics of Hanwoo (Korean native cattle) beef. Meat Sci. 63, 397-405.

9. Kirton, A. H. (1989) Principles of classification and grading.
In: Meat production and processing. Purchas. R. W., ButlerHogg, B. W., and Davies, A. S. (eds), Occasional Publication No. 11, New Zealand Society of Animal Production Inc., NZ, pp. 143-157.

10. Kirton, A. H. and Morris, C. A. (1989) The effect of mature size, sex and breed on patterns of change during growth and development. In: Meat production and processing. Purchas. R. W., Butler-Hogg, B. W., and Davies, A. S. (eds), Occasional Publication No. 11, New Zealand Society of Animal Production Inc., NZ, pp. 73-85.

11. Lawrence, T. E., Farrow, R. L., Zollinger, B. L., and Spivey, K. S. (2008) Technical note: The United States Department of Agriculture beef yield grade equation requires modification to reflect the current longissimus muscle area to hot carcass weight relationship. J. Anim. Sci. 86, 1434-1438.

12. Lee, S. K., Panjono, Kang, S. M., Jung, Y. B., Kim, T. S., Lee, I. S., Song, Y. H., and Kang, C. G. (2008) Effects of tethering and loose housing on the meat quality of Hanwoo bulls. Asian-Aust. J. Anim. Sci. 21, 1807-1814.

13. Lee, J. M., Yoo, Y. M., Park, B.Y., Chae, H. S., Hwang, I. H., and Choi, Y. I. (2005) A research note on predicting the carcass yield of Korean native cattle (Hanwoo). Meat Sci. 69, 583-587.

14. Lindsay, D. B. (1983) Growth and fattening. In: Nutritional physiology of farm animals. Rook. J. A. F. and Thomas, P. C. (eds), Longman, London, UK, pp. 261-313.

15. McBee, J .L. Jr. and Wiles, J. A. (1967) Influence of marbling and carcass grade on the physical and chemical characteristics of beef. J. Anim. Sci. 26, 701-704.

16. Miller, R. K. (1994) Quality characteristics. In: Muscle foods: Meat, poultry and seafood technology. Kinsman. D. M., Kotula, A. W., and Breidenstein, B. C. (eds), Chapman \& Hall, NY, USA, pp. 296-332.

17. Moon, S. S., Hwang, I. H., Jin, S. K., Lee, J. G., Joo, S. T., and Park, G. B. (2003) Carcass traits determining quality and yield grades of Hanwoo Steers. Asian-Aust. J. Anim. Sci. 16, 1049-1054.

18. NLCF (2004) Korean carcass grading standard. National Livestock Cooperatives Federation, Korea.

19. Park, G. B., Moon, S. S., Ko, Y. D., Ha, J. K., Lee, J. G., Chang, H. H., and Joo, S. T. (2002) Influence of slaughter weight and sex on yield and quality of Hanwoo (Korean native cattle) carcasses. J. Anim. Sci. 80, 129-136.

20. Purchas, R. W. (1989) On-farm factors affecting meat quality characteristics. In: Meat production and processing. Purchas. R. W., Butler-Hogg, B. W., and Davies, A. S. (eds), Occasional Publication No. 11, New Zealand Society of Animal Production Inc., NZ., pp. 159-171.

21. Rhee, M. S. and Kim, B. C. (2001) Effect of low voltage electrical stimulation and temperature conditioning on postmortem changes in glycolysis and calpains activities of Korean cattle (Hanwoo). Meat Sci. 58, 231-237.

22. Scollan, N., Hocquette, J. F., Nuernberg, K., Dannenberger, D., Richardson, I., and Moloney, A. (2006) Innovations in beef production systems that enhance the nutritional and health value of beef lipids and their relationship with meat 
quality. Meat Sci. 74, 17-33.

23. SPSS (2003) SPSS Soft for Window. Release 12.0, SPSS Inc., Chicago, USA.

24. Tatum, J. D., Smith, G. C., and Carpenter, Z. L. (1982) Interrelationships between marbling, subcutaneous fat thickness and beef palatability. J. Anim. Sci. 54, 777-784.
25. Turner, J. W., Peltong, L. S., and Cross, H. R. (1990) Using live animal ultrasound measures or ribeye area and fat thickness in yearling Hereford bulls. J. Anim. Sci. 68, 35023506 .

(Received 2008.11.27/Revised 1st 2009.3.19, 2nd 2009.4.9/ Accepted 009.4.12) 